
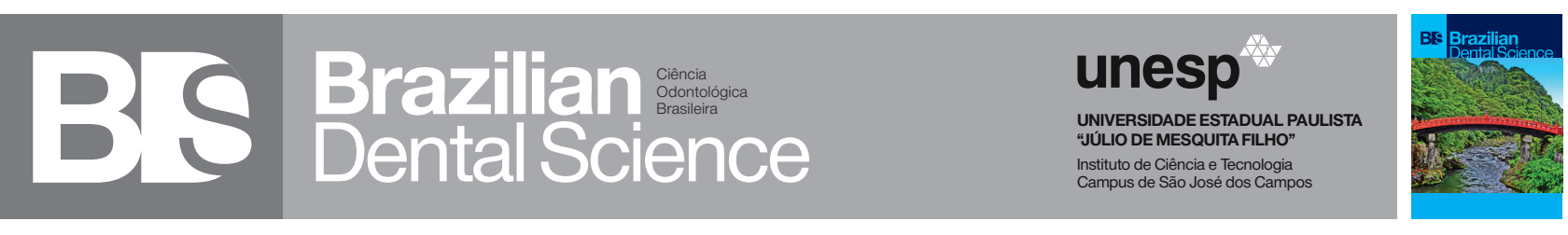

\title{
Evaluation of the epidemiological profile and oral rehabilitation of patients with buccomaxillofacial trauma
}

\author{
Avaliação do perfil epidemiológico e da reabilitação oral de pacientes com traumatismo bucomaxilofacial \\ Ana de Lourdes SÁ DE LIRA¹, João Marques MENDES NETO ${ }^{1}$, Italo José Zacarias PORTELA ${ }^{1}$ \\ 1- Department of Clinical Dentistry - School of Dentistry of State University of Piauí- Parnaíba- PI-Brazil
}

\begin{abstract}
Objective: To obtain the epidemiological profile and follow the rehabilitation of patients with buccomaxillofacial trauma attended at a hospital emergency service. Material and Methods: The study consisted of the analysis of medical charts, evaluation and follow-up of adult patients, over 18 years of age, in the preoperative and postoperative period from August 2015 to July 2016. Of the 114 charts examined, all had their epidemiological profile evaluated, but only 45 patients underwent a maxillofacial surgical procedure. During the clinical evaluation, post-trauma conditions were recorded before treatment (T1) and 48 hours after surgical treatment (T2). Results: The age group most affected by buccomaxillofacial trauma was between 20 and 31 years, especially in the male gender. The mandible and nasal bones were the most affected by trauma. The limitation of mouth opening was the main consequence and the levels of buccal opening before and after treatment of mandible fractures were significantly different. Conclusion: The profile of patients with facial trauma was composed of men, aged between 21 and 30 years, motorcycle traffic accidents and physical aggression being the predominant causal factors. The facial bones most affected by the trauma were the jaw and the nasal bones. The limitation of mouth opening was a consequence of the trauma of the mandibular region. Immediate treatment of fractures that affected the mandible provided the restoration of the maximum opening, occlusion and homeostasis of the stomatognathic system in the postoperative patients.
\end{abstract}

\section{KEYWORDS}

Trauma of head; Traumatology; Fracture fixation.

\section{RESUMO}

Objetivo: Obter o perfil epidemiológico e acompanhar a reabilitação de pacientes com traumatismo bucomaxilofacial atendidos em um serviço de urgência hospitalar. Material e Métodos: A pesquisa consistiu na análise de prontuários, avaliação e acompanhamento de pacientes adultos, acima de 18 anos, no pré e pós-operatório no período de agosto de 2015 a julho de 2016. Dos 114 prontuários examinados, todos tiveram seu perfil epidemiológico avaliado, mas somente 45 pacientes se submeteram a procedimento cirúrgico maxilofacial. Durante a avaliação clínica, as condições pós-trauma foram registradas antes do tratamento (T1) e $48 \mathrm{~h}$ depois do tratamento cirúrgico (T2). Resultados: A faixa etária mais acometida pelo traumatismo bucomaxilofacial foi entre 20 e 31 anos, em especial, no gênero masculino. A mandíbula e o ossos nasais foram os mais afetados pelo traumatismo. A limitação de abertura bucal foi a principal consequência e os níveis de abertura bucal antes e após o tratamento das fraturas de mandíbula foram significativamente diferentes. Conclusão: $\mathrm{O}$ perfil dos pacientes com traumatismo de face foi constituído de homens, faixa etária entre 21 e 30 anos, sendo os acidentes de trânsito com motocicleta e as agressões físicas os fatores causais predominantes. Os ossos faciais mais acometidos pelo traumatismo foram a mandíbula e os ossos nasais. A limitação de abertura bucal foi consequência do trauma da região mandibular. $\mathrm{O}$ tratamento imediato das fraturas que acometeram a mandíbula proporcionou o restabelecimento da abertura máxima, da oclusão e homeostase do sistema estomatognático nos pacientes acompanhados no pós-operatório.

\section{PALAVRAS-CHAVE}

Traumatismo da cabeça; Traumatologia; Fixação de Fratura. 


\section{INTRODUCTION}

B uco-maxillofacial trauma (TBMF) is related to traffic accidents and urban violence, and has grown too much in recent decades, especially in the adult and economically active population, being considered one of the major public health problems in the world [1]. According to the World Health Organization, it is estimated that the number of people who die each year, victims of traffic accidents is approximately 1.2 million individuals, being 50 million people affected each year [2].

Despite the mobilization and encouragement of the use of personal protection accessories in traffic, the incidence in individuals who do not use these accessories is still high, implying the need to redirect health policies in this regard [3].

Many advances have occurred in recent years in the care of trauma victims, such as the primary and secondary correction of these deformities. Among these, the innovative techniques of rigid fixation with plates and screws, besides the use of grafts in the reconstruction of the face [4].

In general, the recovery process after the trauma is time consuming and multiple repair surgeries may be necessary. As it mainly affects the economically active age groups, the financial and social cost of leaving is high [3].

The number is increasing each year, requiring more data referring to the more specific characteristics, so that policies directed to this area of health can be elaborated and the resources better distributed [5].

The rehabilitation process is important, since the patient with facial trauma has his physical and mental state affected and his longings for improvement are reflected in the search for good aesthetic and functional conditions in the post-trauma [6].
The face consists of bones and organs that together contribute to the performance of a multifunctional unit, where the individual manages to meet their main needs and adapt to the social environment in which they live. In this way, lesions, especially in the buccomaxillofacial region, largely lead to functional or aesthetic impairment if not treated properly and efficiently $[2,7]$.

Among the main lesions observed are dentoalveolar lesions, especially those affecting the anterior teeth and compromising both function and aesthetics. Lesions of other adjacent structures may also compromise the function, thus making the rehabilitation process of these patients fundamental [8].

It was hoped to conduct this research to verify if the dental surgeon or bucomaxillofacial specialist is active in the hospital's staff, monitoring and treating the patient with TBMF, aiming at their rehabilitation and improvement in quality of life.

The objective of this research was to obtain the epidemiological profile and follow up the rehabilitation of patients with buccomaxillofacial trauma attended at a hospital emergency service.

\section{MATERIAL AND METHODS}

The study was submitted to the Ethics and Research Committee (CEP) and approved, number 1.835.343. It consisted of a crosssectional, exploratory and quantitative study carried out by the analysis of medical records, evaluation and follow-up of adult patients aged 18 years or over, victims of TBMF treated at the Dirceu Arcoverde State Public Hospital (HEDA), in the municipality of Parnaíba-PI.

All the medical records of the adult patients who suffered traumatic injury of the buccomaxillofacial complex to survey the epidemiological profile and the patients who wished to participate in the study from August 
9, 2015 to July 19, 2016 were included in the study. Minor patients who suffered facial trauma, adults hospitalized for another reasons and those who did not wish to participate in the study were excluded.

The research followed the standards of Res. No 466/12 (CNS / MS). The researcher presented himself with a letter of presentation from UESPI, requesting the authorization of the hospital coordination for the development of the research project.

Among the risks of the research, it was explained to each patient in the Informed Consent Term (TCLE) that there would be a possibility of contagion of infectious diseases at hospital level, for which the researcher used barriers such as lab coat and personal protective equipment (PPE) (gloves, caps and masks). If there was a risk of aggravating the injured or fractured area during the management of the oral cavity in the evaluation, or presence of pain and discomfort, the examination would not be performed.

In order to eliminate the risk of data loss during the evaluation of medical records, they were always kept in the hospital files and collected information properly registered and stored with the researcher. Patient names were not collected, thus maintaining the confidentiality of the information.

The questionnaire with clinical record was applied by two researchers on the morning of Thursday to Monday during the period of the survey, since most hospitalizations for trauma in the hospital occurred on these days of the week.
Patients were examined by researchers who were trained at the Clinical School of Dentistry (CEO) of the State University of Piauí to identify TBMF. Subsequently, calibration exercises were performed with 20 adults not participating in the sample plan, hospitalized for other reasons in HEDA, according to the methodology described in another publication9. The pilot study involving 10 patients was done with the objective of testing the proposed methodology. As a result, its viability was observed, without adjustments. In order to measure intra- and inter-examiner diagnostic reproducibility, 10\% of the total sample was double-checked by each of the examiners, with the Kappa coefficient for intra- and inter-examiner agreement being 0.99 and 0.98 , respectively.

During the clinical evaluation, the posttrauma conditions were recorded in the pretreatment (T1) and 48 hours after the surgical treatment (T2), in order to verify the oral condition and balance of the stomatognathic system, as well as were advised on the necessary treatment and habits less harmful during rehabilitation. Data collection was obtained by examining the medical records and radiographic examinations, as well as applying the questionnaire with a clinical examination card (Figure 1) to the patients by the researcher at the end of the follow-up, in order to facilitate the subsequent analysis of relevant information for the research and the follow-up of the patients in the postoperative period. 


\section{(CLINICAL SHEET)}

Age:

Genre;

Cause of Accident.

Evaluate Oral Cavity

Presence of edema and location:

Dental situation: sign traumatic elements and type of injury
(1) -5
(2) -6 8.7.6.5.4.3.2.1.
1.2.3.4.5.6.7.8
(4) -8
(3) -78.7 .6 .5 .4 .3 .2 .1$
1.2.3.4.5.6.7.8

Dental health (cavities and mobility):

Occlusion: ( ) CII, ( ) Cl II, ( ) Cl III

Bite

Unilateral ( ) open bilateral ( ) posterior deep ( ) open previous ( ) open posterior ( )

Overjet m.m overbite $\mathrm{mm}$.

Midline: central ( ) non-central ( )

Deviation predominant:

- Obvious occlusal interferences:

\section{Rate Movements}

Opening:

Closing: Mandibubres

Condylar movement:

Articular noise:

Maximum opening:

Laterality $\mathrm{E}$ :

Laterality D:

Protrusion:

Fuocionalidade:

Breath: Chew: Swallowing: Speaks:

Figure 1 - The questionnaire with a clinical examination card.

Afterwards, the researchers performed the oral and maxillofacial clinical examination of the patients in the pre-treatment period, immediate post-treatment, orienting the same on oral and alimentary hygiene habits and during the reestablishment of the physiological occlusion while in hospital care. All were referred to the adult clinic of the Dental School Clinic of the State University of Piauí (CEO) for preventive, restorative and rehabilitative dental care. 
The data of each chart, questionnaire, clinical and radiographic exams were cataloged in Microsoft Office Excel software through spreadsheets, and then submitted to statistical analysis. Descriptive statistics (measures of central tendency and dispersion) and construction of graphs were used in order to illustrate the findings of this research. The nonparametric Mann-Whitney test was used to compare the maximum aperture degree between $\mathrm{T} 1$ and $\mathrm{T} 2$, using the significance level of $95 \%$.

\section{RESULTS}

The sample was non-probabilistic consisting of 114 participants whose charts were examined. Of these, 73 (64\%) were males. The majority $(46.6 \%)$, in both genders married or in stable union with age varying from 18 to 87 years (mean 33.48; $\mathrm{SD}=11.74)$. As to ethnicity, the majority of the participants were brown, 24 (21\%) black, $14(12.3 \%)$ white and others (9.3\%). The most observed schooling was the incomplete average (31.6\%), followed by the complete fundamental (24.6\%), fundamental incomplete (22.6\%), complete middle (7\%) and others (12.8\%). In addition, 70 (61.4\%) had some professional activity, 15 (13.2\%) were students, 15 (13.2\%) unemployed men, 6 (5.3\%) unemployed women and 8 people $(7 \%)$ did not declare occupation.

Most of the injuries occurred mainly on Saturdays (50.2\%), Friday (25.4\%) and on Sundays (17.5\%). The hours that took place were between 18: 00-00: 00 hs (50.7\%), from 00:01 to $6: 00$ hs (27.6\%) and between 06: 01-17: 59hs (21.7\%). The distribution of etiological factors was represented in Figure 2.

In this first moment of data collection and analysis, the diagnosis was obtained (Figure 3), totaling 183 injured regions for 114 patients. It was verified that in relation to the factors associated with TBMF, 66 patients were involved with alcohol consumption and $36.8 \%$ of the traumas were caused by motorcycle accidents.

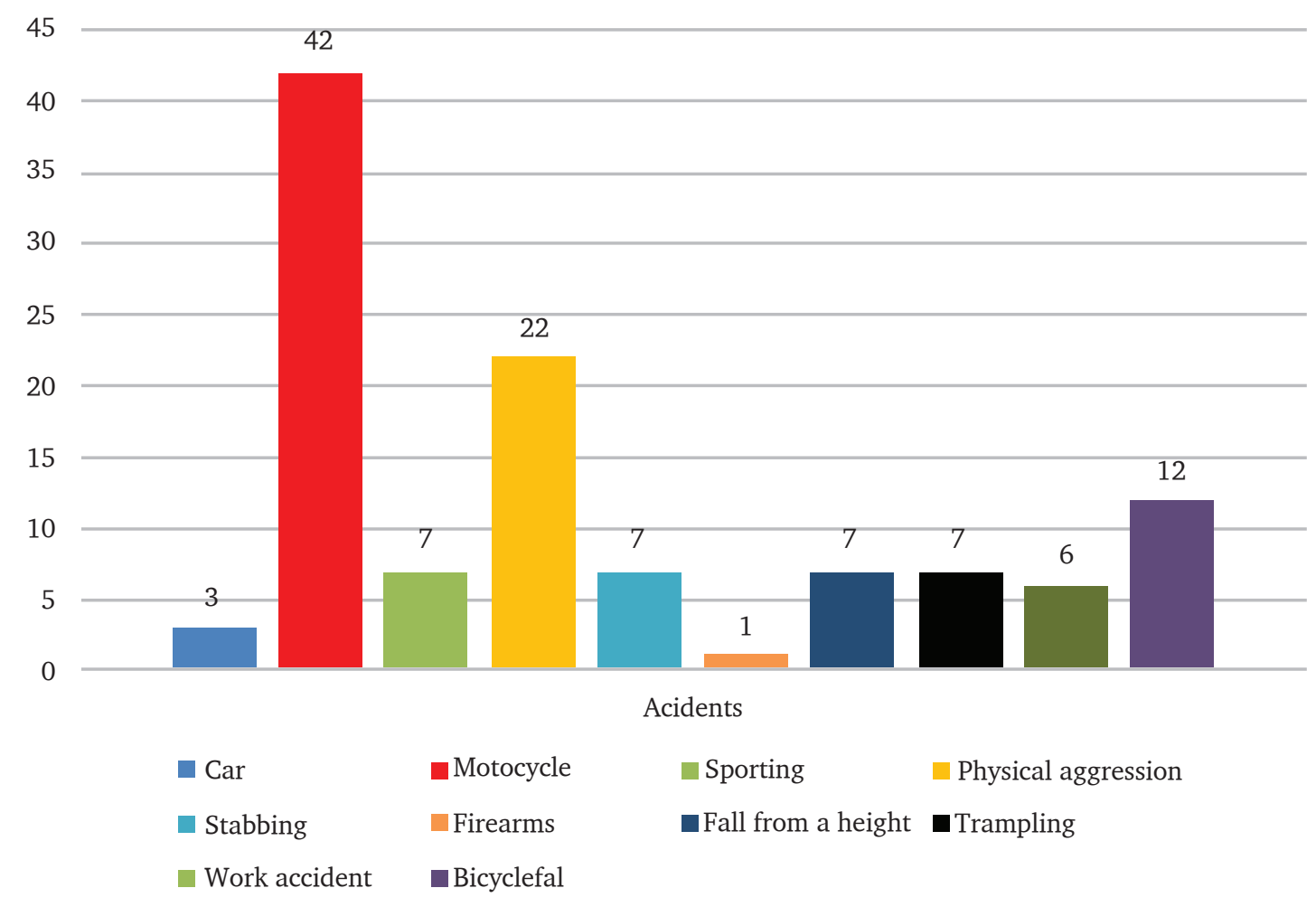

Figure 2 - The distribution of etiological factors. 


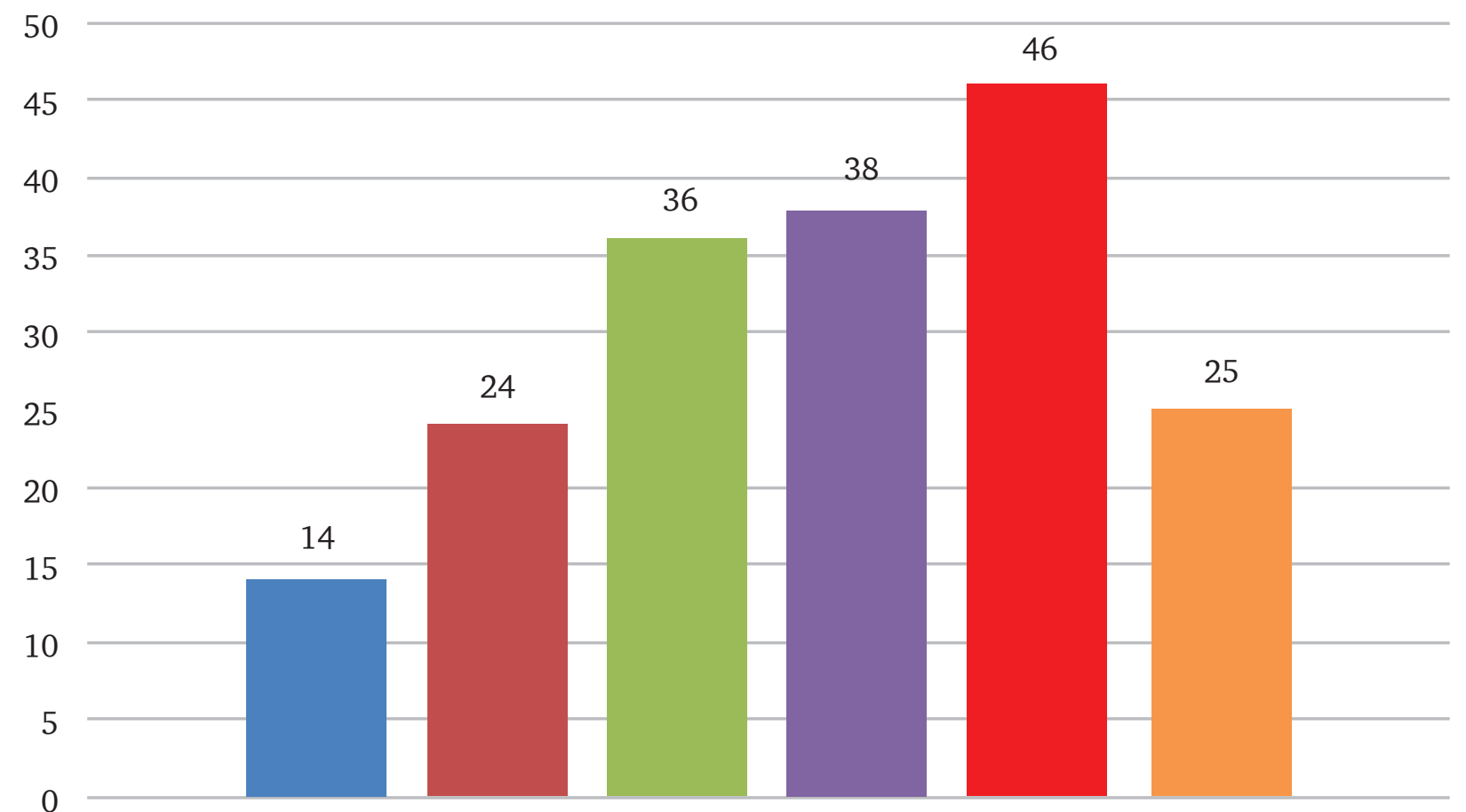

Acidents

Frontal $\square$ Maxillary $\square$ Zigomatic $\square$ Nasal bones $\square$ Mandibule Dento-alveolar

Figure 3 - The distribution of the injured regions.

Only 45 patients underwent a maxillofacial surgery procedures and they were examined in both $\mathrm{T} 1$ and $\mathrm{T} 2$. They were all males, with an average age of 25 years and 10 months. All had mandibular trauma with fracture and were treated surgically. Of these patients, 12 presented maxillary fractures, 8 in the nasal bones and 2 in the zygomatic bone. It is worth noting that the total number of anatomical sites affected is greater than the total number of cases, since some patients had more than one facial region affected.

It was observed that in 23 patients there was dentoalveolar trauma, and in 10 of them, dental avulsions of the 4 upper incisors were observed. In the remaining 13, there was a coronary fracture, involving the upper incisors $(n=8)$ and the central incisors $(n=5)$.
Mandibular movements, specifically the maximum buccal opening test, were selected as an evaluation criterion to verify the restoration of occlusion and balance of the stomatognathic system. The difference in the means between the patients was observed, with (T1) the maximum opening was $20.5 \mathrm{~mm}$ and in (T2) was $40.2 \mathrm{~mm}$.

With the non-parametric Mann-Whitney test, it was found that the difference between the participants in T1 X T2 was highly significant ( $\mathrm{p}$ $<0.001$ ), with a difference between the averages of $19.7 \mathrm{~mm}$ of maximum mouth opening.

It was observed that in 23 patients there was dentoalveolar trauma, and in 10 of them, dental avulsions of the 4 upper incisors were observed. In the remaining 13 , there was a coronary fracture, involving the upper incisors ( 8 cases) and the central incisors (5 cases). 
It was possible to verify by computed tomography that the most commonly affected anatomical structures of the craniofacial region were the mandibular bone and nasal bones.

\section{DISCUSSION}

TBMF varies widely according to gender, age, etiology and associated factors, and the individual is subject to modifying agents [10]. The information contained in the present research comes from data that allow a more direct explanation regarding the etiology and diagnosis made in the service urgency of the HEDA, being of fundamental importance for the organization, planning and improvement of the service.

Regarding gender, $73 \%$ of the charts analyzed were male, with the age group between 21 and 30 years old, corresponding to $30 \%$ of the TBMF. This result was similar to that of other studies in which the same age range was also predominant, corresponding to $33 \%$ of 912 cases and $32.4 \%$ of 139 other evaluated $[11,12]$.

Although traffic accidents were the main cause of TBMF in our study, especially motorcycle accidents, with $36.8 \%$, it is worth highlighting the multifactorial nature of the trauma (Figure 2 ). This result was similar to that of other studies in which they were responsible for $35 \%$ of 250 and $42.9 \%$ of 1041 TBMF [10,11]. However, the most frequent etiology in other studies was physical aggression, with $38.8 \%$ of 711 and $38.2 \%$ of 591 , which confers to the etiology of trauma a heterogeneity according to the population studied $[13,14]$.

Another factor evaluated was the identification of the main anatomical structures affected as result of TBMF (Figure 3). Corroborating with the findings of the present study, the mandible was the bone of the face most affected, probably due to being a mobile bone, more susceptible to fracture $[4,12,15]$.

It was observed that the data are in agreement with other authors regarding the gender, age, number of accidents with motor vehicles and more traumatized bone structure $[14,15,16]$. The high number of traumatic events caused by accidents, which reveals the need for intervention of the competent authorities in this sector so that this framework is reversed, since the number of patients who suffered TBMF and had to undergo surgical procedures was high.

With regard to patients who underwent surgical procedures, both $\mathrm{T} 1$ and $\mathrm{T} 2$, all had marked pain and edema in the mandibular region, and the site of the edema corresponded to the present fracture site.

It was observed that in 23 patients there was dentoalveolar trauma, and in 10 of them, dental avulsions of the 4 upper incisors were observed. In the remaining 13 , there was a coronary fracture, involving the upper incisors (8 cases) and the central incisors (5 cases).

The amount of mouth opening was expected to be limited by the trauma (T1) and improved after surgery (T2), despite edema still present. According to Macedo et al [13], the main symptoms and functional signs in cases of FMMF refer to pain in facial muscles, impairment of mastication and mouth opening due to the limitation and asymmetry of mandibular movements associated or not with joint noise.

During the assessment of mandibular movements in $\mathrm{T} 1$ and $\mathrm{T} 2, \mathrm{~T} 1$ was a limitation of mandibular excursion movements and posterior open bite in all patients. After the surgical procedure there was correction of the posterior open bite in all, since they were strongly associated with the fracture site. Chewing and speech were the main functionalities affected in all cases and respiratory distress in 11 cases. This probably because the jaw and nasal bones were the facial bones most affected by TBMF.

After hospital discharge, only 20 patients who underwent surgical procedures sought dental care at the CEO, probably due to innumerable factors, among them: the already debilitated condition of the patient as a result of the trauma, economic factors since many of them 
resided in other locations and the patients' lack of perception and understanding of the importance of the rehabilitation process.

\section{CONCLUSION}

The predominant profile of patients with buccomaxillofacial trauma was men, aged between 21 and 30 years, with incomplete secondaryeducation, exercising some professional activity, motorcycle traffic accidents and physical aggression being the most evident causal factors.

The bones of the face most affected by the trauma were the jaw and the nasal bones.

The limitation of mouth opening was a consequence of the trauma of the mandibular region. Immediate treatment of fractures that affected the mandible provided the restoration of the maximum opening, occlusion and homeostasis of the stomatognathic system in the postoperative patients.

Social and community actions should be stimulated in schools, clubs and workplaces, since research has pointed to the growth of automobile accidents, especially motorcycles, and interpersonal aggression, predisposing to buccal and maxillofacial traumatism.

The interpretation of the results should consider some limitations inherent to this study. It is important that future studies are carried out to arouse the interest of the authorities in the elaboration of health policies aiming at the prevention of oral and maxillofacial trauma.

\section{REFERENCES}

1. Silva JJL, Lima AAS, Torres SM. Fraturas de face: análise de 105 casos. Rev Soc Bras Cir Craniomaxilofacial. 2007;10(2):41-50. doi:10.1590/1516-4187
2. Smets LM, Van Damme PA, Stoelinga PJ. Non-surgical treatment of condylar fractures in adults: a retrospective analysis. J Craniomaxillofac Surg. 2003;31(3):162-7.

3. Montovanl JC, Campos LMP, Gomes MA, Moraes VRS, Ferreira FD, NogueiraE A. Etiologia e incidência das fraturas faciais em adultos e crianças: experiência em 513 casos. Rev Bras Otorrinolaringologia. 2006;72(2):235-41. doi 10.1590/ S0034-72992006000200014

4. Freitas DA, Caldeira VL, Pereira MZ, Silva MA, Freitas AV, Antunes ONLS. Estudo epidemiológico das fraturas faciais ocorridas na cidade de Montes Claros/MG. Rev Bras Cirur Cabeça Pescoço. 2009;38(2):113-5.

5. Adeyemo WL, Ladeinde LA, Ogunlewe OM, James 0 . Trends and characteritcs of oral and maxillofacial infuries in Nigéria: a review of the literature. Head Face Med. 2005;17):1-9. doi:10.1186/1746-160X-1-7.

6. Camarini TE, Pavan JA, Filho IL, Barbosa BEC. Estudo epidemiológico dos traumatismos bucomaxilofaciais na região metropolitana de MaringaPRentre os anos de 1997 e 2003. Rev Cirur Traum BucoMaxiloFacial. 2004;4(2):131-5.

7. Brasileiro B, Passeri LA. Epidemiologic analysis of maxillofacial fracture in Brazil: A year prospective study. Oral Surg Oral Med Oral Pathol Radiol Endo. 2006;102(1):28-34. doi: 10.1016/j.triple0.2005.07.023.

8. Santos ASK, Monteiro BVB, Fernandes VL, Neto CGL Tratamento de traumatismos dentoalveolares e reabilitação protética em paciente jovem relato de caso. Odontol. Clín Cient. 2010;9(2):181-4.

9. Peres MA, Traebert J, Marcenes W. Calibration of examiners for dental caries epidemiology studies. Cad Saúde Pública. 2001 Jan-Feb;17(1):153-9. doi: 10.1590/S0102-311X2001000100016.

10. Pereira MD, Tessie K, Almeida RS, Ferreira LM. Trauma craniofacial: perfil epidemiológico de 1223 fraturas atendidas entre 1999 e 2005 no Hospital São Paulo - UNIFESP-EPM. Rev Soc Bra Cir Craniomaxilofacial. 2008;2(11):47-50.

11. Scannavino FLF.Análise epidemiológica dos traumas bucomaxilofaciais de um serviço de emergência. Rev Cir Traumatol BucoMaxiloFac. 2013;13(4):95100. doi:10.1590/1808-5210.

12. Bresaola MD, Assis DSFR, Ribeiro Júnior PD. Avaliação epidemiológica de pacientes portadores de traumatismo facial em um serviço de prontoatendimento da Região Centro-Oeste do Estado de São Paulo. Rev Odont. 2005;7(3):50-7.

13. Macedo JLS, Camargo LM, Almeida PF, Rosa SC. Perfil epidemiológico do trauma de face dos pacientes atendidos no pronto socorro de um Hospital Público. Rev Col Bras Cir. 2008;35(1):9-13. doi.10.1590/S010069912008000100004.

14. Tino MT, Andrade AF, Gonçalves JA, Freitas RR. Epidemiologia do trauma maxilofacial num hospital universitário terciário da cidade de São Paulo. Rev Bras Cir Cabeça Pescoço. 2010;39(2):139-45.

15. Martins Júnior JC, Keim FS, HelenaETS. Aspectos Epidemiológicos dos Pacientes com Traumas Maxilofaciais Operados no Hospital Geral de Blumenau, SC de 2004 a 2009. Arq Int Otorrinolaryngol;2010;14(2):192-8. doi 10.4432/S12000-00035.

16. Wulkan M, Parreira GJ, Botter AD. Epidemiologia Do Trauma Facial. Rev Ass Med Bras. 2005;51(5):290-5. doi.10.1590/S0104-42302005000500022.

\author{
Ana de Lourdes Sá de Lira \\ (Corresponding address) \\ Universidade Estadual do Piauí, Faculdade de Odontologia \\ Rua Senador Joaquim Pires 2076 Ininga. \\ Fone (86) 999595004 \\ CEP: 64049-590 Teresina-PI-Brasil \\ email: anadelourdessl@hotmail.com
}

Date submitted: 2017 Nov 14 Accept submission: 2018 Apr 12 